\title{
ДО ПИТАННЯ ПРО СТАНДАРТИ ПРОТИДІЇ КОРУПЦІї В ЧИННОМУ ЗАКОНОДАВСТВІ УКРАЇНИ
}

Кузніченко О. В.

Статтю присвячено аналізу стандартів (принципів), які покладено в основу чинного законодавства України у сфері протидії корупції. Окрему увагу в статmі приділено аналізу сучасного стану розвитку законодавства України в даній сфері та питанням приведення його у відповідність до європейських стандартів у цій сфері.

Актуальність цієї проблематики зумовлюється тим, що сьогодні питання розв'язання проблеми запобігання та протидії корупції є одним із пріоритетних для української держави та суспільства. I ия проблема, на жаль, набула глобального та системного характеру в різних сферах діяльності органів державної влади та управління.

Констатується, що європейський нормативноправовий механізм боротьби з корупцією базується на таких стандартах (принципах), як: верховенство права; законність, системність; комплексність; об'єктивність; практична спрямованість заходів; наукова обґрунтованість; економічна доцільність; взаємодія владних структур з інститутами суспільства і населенням; оптимальність та ефективність; об'єктивність. Окрема увага приділяється аналізу змісту європейських конвенцій у сфері боротьби з корупцією, зокрема Цивільної конвенції про боротьбу з корупцією, Кримінальної конвенції про боротьбу з корупцією та Конвенції про відмивання, пошук, арешт та конфіскацію доходів, одержаних злочинним шляхом, які $\epsilon$ частиною національного законодавства України.

Доводиться теза про те, що боротьба з корупцією протягом останніх років постійно проголошувалась серед основних пріоритетів Української держави. Разом із тим і дотепер Україна є державою з надзвичайно високим рівнем корупціі, яка наразі загрожує національній безпеці. Констатується, що чинна нормативно-правова база, що забезпечує боротьбу з корупцією в Україні, з одного боку, є досить широкою, з іншого - застарілою в ряді аспектів та системно недовершеною.

Резюмується, що в процесі імплементації в національне антикорупційне законодавство стандартів міжнародного та європейського рівня нагальними завданнями $\epsilon$ розроблення та прийняття норма-

(c) Кузніченко О. В., 2020 тивно-правових актів, спрямованих на вдосконалення регламентації таких питань, як: конфлікт інтересів у діяльності публічних службовців; правила професійної етики на публічній службі та запобігання конфлікту інтересів; державний фінансовий контроль публічної служби; державний контроль за декларуванням доходів, майна та витрат осіб, уповноважених на виконання функцій публічної влади.

Ключові слова: протидія корупції, антикорупційне законодавство, європейські стандарти у сфері протидії корупції, Рада Європи.

Kuznichenko 0 . V. To the question on standards of anti-corruption in the current legislation of Ukraine

The article is devoted to the analysis of standards (principles), which are the basis of the current legislation of Ukraine in the field of anti-corruption. Special attention in the article is paid to the analysis of the current state of development of Ukrainian legislation in this area and the issues of bringing it into line with European standards in this area.

The topicality of this issue is conditioned by the fact that nowadays solving the problem of preventing and combating corruption is one of the priorities for the Ukrainian state and society. And this problem, unfortunately, became of global and systemic character in in various spheres of activity of public authorities and administrative bodies.

It is stated that the European legal mechanism for combating corruption is based on such standards (principles) asrule of law; legality, systematics; complexity; objectivity; practical orientation of measures; scientific validity; economic feasibility; interaction of power structures with institutions of society and population; optimality and efficiency; objectivity. Special attention is paid to the analysis of the European conventions in the field of anticorruption, in particular, the Civil Convention against Corruption, the Criminal Convention for the Suppression of Corruption and the Convention on Laundering, Search, Seizure and Confiscation of the Proceeds from Crime, that are the part of the domestic legislation of Ukraine.

It is proved that the fight against corruption in recent years has been constantly proclaimed among the main priorities of the Ukrainian state. At the same time, Ukraine is still a country with an extremely high level of corruption, which currently threatens national security. It is stated that the current regulatory framework for combating corruption in Ukraine, on the one hand, 
is quite broad, on the other - outdated in some respects and systemically incomplete.

It is summarized that in the process of implementation of international and European standards in the national anti-corruption legislation, the urgent tasks are the development and adoption of regulations aimed at improving the regulation of the following issues: conflict of interest in the activities of public servants; rules of professional ethics in the public service and prevention of conflicts of interest; state financial control of public service; state control over the declaration of income, property and expenses of persons authorized to perform public authority functions.

Key words: anti-corruption, anti-corruption legislation, European standards in the field of anticorruption, Council of Europe.

Постановка проблеми та іï актуальність. Корупція $\epsilon$ основною загрозою соціально-економічному розвитку будь-якого суспільства. Вона $\epsilon$ не лише основною причиною бідності країни, але й перешкодою для іï подолання. Корупція може загрожувати існуванню нації, оскільки корупційні дії та їхні наслідки можуть позначитися на житті наступних поколінь. Убачається, що на високий рівень корупції в Україні впливають такі фактори: непрозорість діяльності й недостатня підзвітність органів державної влади; відсутність політичної волі щодо боротьби з корупцією, неактивна участь у цій боротьбі правоохоронних структур і органів національної безпеки держави; надмірний вплив окремих олігархічних груп на прийняття державних рішень і кадрові призначення; відсутність системності в роботі з виявлення корупції в органах державної влади; недостатній рівень публічного контролю за доходами та видатками вищих посадових осіб держави та ін.

У правовій державі не може бути інших засобів боротьби з корупцією, крім правових. Протидія корупції може бути ефективною лише за умови, якщо вона ґрунтується на правовій основі. 3 огляду на це засоби боротьби з корупцією, які, хоча і можуть виявитись ефективними, однак ідуть усупереч конституційним засадам функціонування держави та суспільства, $€$ неприйнятними [1].

Аналіз останніх публікацій i досліджень. Вирішенню різних аспектів проблем корупційної злочинності та вдосконаленню вітчизняного антикорупційного законодавства, зокрема кримінального, присвячено праці вчених у галузі кримінології та кримінального права: П.П. Андрушка, Ю.В. Бауліна, С.В. Дрьомова, О.М. Костенка, О.Г. Кулика, О.М. Литвинова, П.С. Матишев- ського, А.В. Савченка, О.Я. Свєтлова, Є.Д. Скулиша, В.В. Сташиса, І.К. Туркевича, Г.О. Усатого, М.І. Хавронюка, С.А. Шалгунової та інших, а також учених інших спеціальностей: Н.С. Карпова, Ю.Г. Кальниша, Г.А. Матусовського, Є.В. Невмержицького, О.В. Терещука, В.М. Трепака тощо.

Метою статті $є$ здійснити комплексний аналіз стандартів (принципів), на яких ґрунтується чинне законодавство України у сфері протидії корупції, та сформувати законодавчі пропозиції в контексті приведення антикорупційного законодавства України у відповідність до європейських стандартів.

Виклад основного матеріалу. Сьогодні боротьба з корупцією $є$ одним із найважливіших аспектів діяльності органів влади в розвинутих європейських державах, у тому числі й в Україні. Ця боротьба проводиться системно і базується на таких стандартах (принципах), як: верховенство права; законність, системність; комплексність; об'єктивність; практична спрямованість заходів; наукова обґрунтованість; економічна доцільність; взаємодія владних структур з інститутами суспільства і населенням; оптимальність та ефективність; об'єктивність.

Розглянемо їх докладніше.

Верховенство права означає, що за здійснення протидії корупції людина, іï права та свободи визнаються найвищими соціальними цінностями та визначають зміст і спрямованість антикорупційної діяльності.

Законність передбачає, що всі антикорупційні заходи повинні базуватися на положеннях Конституції та законів. Жодні міркування не можуть виправдати застосування антикорупційних заходів, які не відповідають закону. Відсутність законодавчої основи для вжиття таких заходів $€$ підставою для розроблення і прийняття відповідних нормативно-правових актів [5, с. 306-310].

Системність потребує, щоб заходи протидії корупції були взаємопов'язаними, мали певний субординаційний характер та порядок виконання (головні та другорядні, негайні для виконання i розраховані на перспективу, одноразові й такі, що мають здійснюватися постійно) і підпорядковувалися стратегічній меті антикорупційної діяльності. Важливим при цьому є визначення головної проблеми протидії корупції і концентрації на їі розв'язанні основних зусиль. Це може бути проблема прийняття відповідного закону, утворення певного державного органу, проведення адміністративної реформи, вдосконалення системи контролю за прибутками та витратами осіб, уповноважених на виконання функцій держави, тощо. 
Комплексність протидії корупції передбачає органічне поєднання стратегічних i тактичних завдань, профілактичних (соціального, політичного, економічного, організаційно-управлінського, правового, соціально-психологічного та іншого характеру), оперативно-розшукових, процесуальних, репресивних та інших заходів, які здійснюються в різних соціальних сферах різними суб'єктами, з визначенням пріоритету профілактичних заходів загально-соціологічного і спеціально-кримінологічного характеру [13, с. 682-689].

Об'єктивність вимагає узгодження заходів протидії корупції з закономірностями й тенденціями розвитку корупції в державі, іiі впливом на економічні, політичні, соціальні процеси. Він передбачає здійснення протидії корупції з урахуванням загальної соціально-економічної ситуації в країні і вибір антикорупційних засобів за принципом їхньої достатності для досягнення поставленої мети й адекватності суспільній небезпеці корупційних проявів.

Цей стандарт безпосередньо пов'язаний зі стандартом практичної спрямованості та радикальності, передбачає реальний, не декларативний характер заходів, що здійснюються. Вони повинні мати не характер політичної кампанії, а безпосередньо впливати на фактори, що детермінують корупцію. Практична спрямованість антикорупційних заходів потребує чіткого визначення суб'єктів протидіï, їх завдань і повноважень, конкретності заходів та строків їх виконання тощо [14, с. 129-133].

Наукова обґрунтованість як стандарт передбачає здійснення антикорупційної діяльності на науковій основі - з використанням сучасних досягнень науки, техніки, позитивного світового досвіду, із залученням фахівців із таких галузей, як теорія права, конституційне, фінансове, адміністративне, кримінальне, податкове право, кримінологія, соціологія, психологія тощо. Цей принцип зобов'язує піклуватися про повну і всебічну кримінологічну інформацію в країні, регіоні, галузі, установі, а тому, зокрема, передбачає постійне здійснення моніторингу органів державної влади та органів місцевого самоврядування на предмет стану та динаміки корупційних процесів. Такий моніторинг необхідний для оцінки ефективності реалізації в державі антикорупційної політики, зміни ії пріоритетів відповідно до ситуації з корупцією, вироблення та втілення нових антикорупційних заходів [3, с. 3-13].

Економічну доцільність також слід розглядати як відповідний стандарт, який передбачає, що антикорупційні заходи мають бути економічно обґрунтованими як 3 точки зору їхньої економічної ефективності, так і можливих негативних побічних наслідків, а також реальної економічної можливості їх впровадження в життя. Можливими $\epsilon$ планування і розроблення лише тих заходів, які на сучасному етапі держава спроможна впровадити в життя з урахуванням наявної економічної ситуації. Проте економічний раціоналізм не означає мінімізації витрат на протидію корупції, вони повинні зумовлюватись економічними можливостями держави і водночас бути достатніми [1].

Взаємодія владних структур з інститутами громадянського суспільства і населенням загалом як стандарт потребує в протидії корупції поєднання зусиль владних структур і суспільних інституцій. Протидія корупції - справа всього суспільства, кожен суспільний інститут має виконувати свою функцію, в межах своїх повноважень та компетенції вживати всіх можливих антикорупційних заходів. Обмеження протидії корупції правоохоронною діяльністю відповідних державних органів не забезпечить виконання основних завдань і досягнення мети антикорупційної діяльності [14, c. 129-133].

Далі проаналізуємо сучасний стан розвитку національного законодавства у сфері протидії корупції та сформуємо законодавчі пропозиції в контексті приведення антикорупційного законодавства України у відповідність до європейських стандартів.

Як відомо, боротьба з корупцією протягом останніх двадцяти п'яти років постійно проголошувалась серед основних пріоритетів Української держави. Проте й дотепер Україна $\epsilon$ державою з надзвичайно високим рівнем корупції, яка наразі загрожує національній безпеці.

При цьому чинна нормативно-правова база, що забезпечує боротьбу 3 корупцією в Україні, з одного боку, $\epsilon$ досить широкою, з іншого - застарілою в ряді аспектів та системно недовершеною. До правових актів, що регулюють відносини у вказаній сфері, належать: Кримінальний кодекс України 2001 р. (у редакції від 30.12.2020 р. [4]); Кодекс України про адміністративні правопорушення 1984 р. (у редакції від 01.01.2021 р. [2]); закони України: «Про організаційно-правові основи боротьби з організованою злочинністю», 1993 р. (в редакції від 03.07.2020 р. [11]); «Про державну службу», 2015 р. (у редакції від 15.01.2021 р. [6]), «Про запобігання та протидію легалізації (відмиванню) доходів, одержаних злочинним шляхом, фінансуванню тероризму 
та фінансуванню розповсюдження зброї масового знищення», 2014 р. (у редакції від 16.08.2020 р. [9]); «Про доступ до публічної інформації», 2011 р. (у редакції від 24.10.2020 р. [7]); «Про запобігання корупції» від 14 жовтня 2014 року (у редакції від 30.12.2020 р. [8]); «Про Національне антикорупційне бюро України» від 14 жовтня 2014 року (у редакції від 16.09.2020 р. [10]) та інші.

Протягом останніх років було прийнято низку нормативно-правових актів у сфері протидії корупції та ратифіковано низку міжнародно-правових актів, спрямованих на забезпечення практичних заходів щодо подолання корупції. Йдеться про Конвенцію Ради Європи про запобігання тероризму 2005 р.; Протокол, що вносить зміни до Європейської конвенції про боротьбу з тероризмом 2003 р.; Конвенцію Організації Об'єднаних Націй проти корупції 2003 р.; Кримінальну конвенцію про боротьбу з корупцією 1999 р. та Додатковий протокол до неї, 2003 р.; Угоду про незаконний обіг на морі, укладену на виконання статті $17 \mathrm{Koн-}$ венції Організації Об'єднаних Націй про боротьбу з незаконним обігом наркотичних засобів та психотропних речовин, 1995 р. та ін.

Незважаючи на низку заходів, зокрема нормативного характеру, спрямованих на подолання корупції, існує ціла низка проблем у сфері правової регламентації боротьби з цим явищем в Україні. До таких належать насамперед недоліки в регламентації роботи органів, які здійснюють боротьбу з організованою злочинністю та корупцією; неналежний рівень матеріального забезпечення працівників правоохоронних органів та державних службовців; недосконалість процедури вилучення та конфіскації доходів, отриманих злочинним шляхом тощо.

До числа основних європейських стандартів у сфері боротьби з корупцією слід віднести такі, як:

1) взаємодія владних структур 3 інститутами суспільства і населенням у боротьбі з корупцією (Конвенція ЄС про боротьбу з корупцією 1997 р.);

2) ефективний правовий захист осіб, яким заподіяно шкоду внаслідок корупційних дій, та відповідальність держави за таку шкоду (Конвенція ЄС про боротьбу з корупцією 1997 р.);

3) невідворотність та дієвість покарання за корупційний злочин (Конвенція ЄС про боротьбу з корупцією 1997 р.);

4) заборона покарання двічі за один той самий корупційний злочин (Конвенція ЄС про боротьбу з корупцією 1997 р.);

5) превентивність покарання за корупційний злочин (Конвенція ЄС про боротьбу з корупцією 1997 р.);
6) заборона особі, що здійснювала корупційне діяння, в здійсненні діяльності на аналогічній посаді або в аналогічній якості (Рамкове рішення Ради 2003/568/ЮВС від 22 липня 2003 р.)

3 метою приведення антикорупційного законодавства України у відповідність до європейських стандартів убачається доцільним сформулювати такі законодавчі пропозиції:

1. Проблема полягає в тому, що вже майже три роки в Україні немає основного стратегічного документа у сфері запобігання та протидії корупції - Антикорупційної стратегії. Це призвело до розбалансованої і малоефективної діяльності органів державної влади, органів місцевого самоврядування та інших публічних інституцій у питаннях запобігання та протидії корупції. Таким чином, існує нагальна потреба в ухваленні нових засад державної антикорупційної політики, які визначатимуть першочергові заходи із запобігання та протидії корупції, що повинні вплинути на зниження рівня корупції в Україні. Отже, вбачається, що нагальним завданням вітчизняного законодавця $\epsilon$ найскоріше схвалення в другому читанні проекту Закону України «Про засади державної антикорупційної політики на 2020-2024 роки» (реєстр. № 4135 від 21.09.2020 р. [12]).

2. Доцільним видається також внести зміни до Закону України «Про центральні органи виконавчої влади» та законів про статус окремих органів влади щодо запровадження процедур формування та діяльності громадських рад при цих органах, здійснення громадського контролю та експертизи, щорічного зовнішнього антикорупційного аудиту органів незалежними експертно-аудиторськими структурами.

3. Внесення змін до КПК України та Закону України «Про запобігання корупції» щодо посилення правових гарантій потерпілим та цивільним позивачам у справах про корупційні дії. Слід також передбачити можливість розгляду кримінального провадження судом присяжних за ініціативи потерпілого або цивільного позивача, внесення змін до КК України щодо подовження термінів давності стосовно осіб, підозрюваних чи обвинувачених у вчиненні тяжких або особливо тяжких корупційних злочинів.

Висновки. 3 огляду на існуючі в цій сфері стандарти міжнародного та європейського рівня нагальними завданнями видаються й розроблення та прийняття нормативно-правових актів, спрямованих на удосконалення регламентації таких питань, як: конфлікт інтересів у діяльності публічних службовців; правила професійної етики на 
публічній службі та запобігання конфлікту інтересів; державний фінансовий контроль публічної служби; державний контроль за декларуванням доходів, майна та витрат осіб, уповноважених на виконання функцій публічної влади.

\section{Література}

1. Актуальні проблеми боротьби з корупцією в контексті євроатлантичної інтеграції. «Оцінка ризиків та загроз національній безпеці в контексті європейської і євроатлантичної інтеграції України» : матер. Між нар. наук.-практ. конф. 14.07.2006. Київ, 2006.

2. Кодекс України про адміністративні правопорушення (статті 1 - 212-21) : Закон, Кодекс від 07.12.1984 р. № 8073-Х. Офічійний сайт Верховної Ради України. URL: http://zakon3.rada.gov.ua/rada/ show/80731-10

3. Корнієнко М.В. Проблеми боротьби з корупцією та шляхи їх розв'язання. Науковий Вісник $H A B C$ України. Науково-теоретичний журнал. 2003. Ч. 2. № 1. С. 3-13.

4. Кримінальний кодекс України: Закон України від 05.04.2001 р. № 2341-III. Офіційний сайт Верховної Ради України. URL: http://zakon5.rada.gov.ua/ $\mathrm{rada} / \mathrm{show} / 2341-14$

5. Михайленко П. П. Значение принципа законности и его обеспечение при расследовании преступлений. Проблемы борьбы с коррупцией и организованной преступностью : НДІ «Проблемы человека». Київ, 1998. С. 306-310.

6. Про державну службу : Закон України від 10.12.2015 р. №889-VIII. Офіційний сайт Верховної Ради України. URL: http://zakon0.rada.gov.ua/rada/ show/889-19

7. Про доступ до публічної інформації : Закон України від 13.01.2011 р. № 2939-VI. Офіційний сайт Верховної Ради України. URL: http:// zakon0.rada.gov.ua/rada/show/2939-17
8. Про запобігання корупції : Закон України від 14.10.2014 р. № 1700-VII. Офіційний сайт Верховної Ради України. URL: http://zakon0.rada.gov.ua/rada/ show $/ 1700-18$

9. Про запобігання та протидію легалізації (відмиванню) доходів, одержаних злочинним шляхом, або фінансування тероризму : Закон України від 14.10.2014 № 1702-VII. Офіційний сайт Верховної Ради України. URL: http://zakon2.rada.gov.ua/rada/ show/1702-18

10. Про Національне антикорупційне бюро України : Закон України від 14.10.2014 р. № 1698-VII. Офіційний сайт Верховної Ради України. URL: http://zakon5.rada.gov.ua/rada/show/1698-18

11. Про організаційно-правові основи боротьби з організованою злочинністю : Закон України від 30.06.1993 р. №3341-XII. Офіційний сайт Верховної Ради України. URL: http://zakon2.rada.gov.ua/rada/ show/3341-12

12. Проект Закону України «Про засади державної антикорупційної політики на 2020-2024 роки» (реєстр. № 4135 від 21.09.2020р.). URL: http:// w1.c1.rada.gov.ua/pls/zweb2/webproc4_1?pf3511=70007

13. Сервецький І.В. Боротьба з організованою злочинністю та корупцією в Україні - умови розвитку економічних відносин і теоретичних аспектів. Економіка України: реалії, перспективи розвитку ринкових відносин: аналітичні розробки, пропозиції науковців та практичних працівників. Київ, 2000. T. 20. C. 682-689.

14. Шевченко О.В. Основні принципи протидії корупції. Вісник Вищої ради юстиції. 2011. № 1 (5). C. 129-133.

Кузніченко О. В., кандидат юридичних наук, доцент, доцент кафедри цивільно-правових дисциплін одеського державного університету внутрішніх справ 